\title{
$\beta$-Lactamase of Lysobacter enzymogenes: induction, purification and characterization
}

\author{
RichaRd G. VON Tigerstrom* and GREgORY J. BORAS \\ Department of Microbiology, University of Alberta, Edmonton, Alberta T6G 2E9, Canada
}

(Received 4 September 1989; revised 27 November 1989; accepted 11 December 1989)

\begin{abstract}
Lysobacter enzymogenes produces an inducible $\beta$-lactamase and induction with $100 \mu \mathrm{g}$ ampicillin $\mathrm{ml}^{-1}$ resulted in an increase of more than 100-fold in enzyme activity. Various other $\beta$-lactam antibiotics also served as effective inducers. The enzyme was obtained from cells by osmotic shocking to release periplasmic components and it was purified primarily by ion-exchange chromatography and PAGE. The $\beta$-lactamase consists of one polypeptide with a molecular mass of about $28 \mathrm{kDa}$ and an isoelectric point greater than 9.6. It is strongly inhibited by $p$ chloromercuribenzoate and clavulanic acid but not by EDTA. The enzyme readily hydrolyses several penicillins and cephalosporins, but not oxacillin or cloxacillin. The enzyme therefore belongs to group $2 \mathrm{~b}$ of the bacterial $\beta$-lactamases.
\end{abstract}

\section{Introduction}

Lysobacter enzymogenes and related species are Gramnegative gliding bacteria noted for the production of extracellular enzymes which have a role in biodegradation (Christensen \& Cook, 1978; Reichenbach \& Dworkin, 1981; Rosenberg \& Varon, 1984). A number of these enzymes have been studied in detail. The proteases (Jackson \& Matsueda, 1970; Whitaker, 1970), the chitinase (Hedges \& Wolfe, 1974), the nucleic acid hydrolases (von Tigerstrom, 1980, 1981), a phosphatase (von Tigerstrom, 1984), an amylase and an esterase (von Tigerstrom \& Stelmaschuk, 1987, 1989) were found to be secreted into the exterior milieu, mainly after the exponential growth phase. Another phosphatase (von Tigerstrom \& Stelmaschuk, 1986) and another esterase (von Tigerstrom \& Stelmaschuk, 1989) are associated with the outer membrane.

Little is known about the periplasm of these organisms or about the effect of the production of secreted hydrolases on the integrity of the outer membrane and the periplasmic components. For instance, it is possible that some of the hydrolases found in the exterior milieu could have come from the periplasm. Therefore, in order to study the secretion and localization of enzymes in

Abbreviations: PADAC, 7-(thienyl-2-acetamido)-3-[2-(4- $N, N$,-dimethyl-aminophenylazo)-pyridinium methyl]-3-cephem-4-carboxylic acid; $p$ CMB, $p$-chloromercuribenzoate; $p$ CMBS, $p$-chloromercuribenzenesulphonic acid.
L. enzymogenes, it will be important to have a periplasmic marker enzyme.

Christensen \& Cook (1978) reported that most species of Lysobacter are resistant to 10 units of penicillin G. To our knowledge, there have not been any reports of $\beta$-lactamases from Lysobacter species or related gliding bacteria (Bush, $1989 a, b, c)$. It was not known, therefore, whether the resistance to penicillin was due to a $\beta$ lactamase, to structural constraints imposed by the outer membrane or to a low affinity of the penicillin-binding proteins for penicillin.

Recently we found that $L$. enzymogenes produces a $\beta$ lactamase which appears to be located in the periplasm. This paper describes the induction of the $\beta$-lactamase, as well as the purification and some properties of the enzyme.

\section{Methods}

\footnotetext{
Chemicals. The $\beta$-lactamase substrate PADAC [7-(thienyl-2-acetamido)-3-[2-(4- $N, N$-dimethyl-aminophenylazo)-pyridinium methyl]-3cephem-4-carboxylic acid] was obtained from Calbiochem and all other $\beta$-lactams were purchased from Sigma. The protein standards phosphorylase $b$, ovalbumin, $\alpha$-chymotrypsin and cytochrome $c$ from horse heart also were from Sigma, whereas the bovine serum albumin (BSA) and chymotrypsinogen A were from Pierce. Bovine pancreatic ribonuclease was the product of the Worthington Biochemical Corporation, $p$-chloromercuribenzenesulphonic acid ( $p$ CMBS) and $p$-chloromercuribenzoate ( $p \mathrm{CMB}$ ) were obtained from Sigma and clavulanic acid was a gift from Dr S. E. Jensen of the Department of Microbiology, University of Alberta.
} 
Organism and culture conditions. Lysobacter enzymogenes UASM 495 (ATCC 29487) was obtained from Dr F. D. Cook, Department of Soil Microbiology, University of Alberta. It was grown at $22{ }^{\circ} \mathrm{C}$ in $1 \%(w / v)$ yeast extract on an orbital shaker at 250 r.p.m. To obtain a growing culture with induced levels of $\beta$-lactamase, ampicillin $\left(100 \mu \mathrm{g} \mathrm{ml}^{-1}\right)$ was added immediately after the medium was inoculate 1 with stationary-phase cells to a cell density of $0.8 \mathrm{OD}_{600}$. The culture was then grown to an $\mathrm{OD}_{600}$ of about 3.5. Other $\beta$-lactam antibiotics were also added to the medium to a concentration of $100 \mu \mathrm{g} \mathrm{ml}^{-1}$ and nonspecific inducers (Sanders, 1987) such as tryptophan, glycine, haemin and thiamin were used at $500 \mu \mathrm{g} \mathrm{ml}^{-1}$. The cell-free extract was prepared as described previously (von Tigerstrom \& Stelmaschuk, 1989).

Enzyme assays. $\beta$-Lactamase was assayed in a Perkin Elmer $\lambda 3$ spectrophotometer with recorder at a constant temperature of approximately $22^{\circ} \mathrm{C}$. A typical reaction mixture contained $850 \mu \mathrm{l}$ $50 \mathrm{~mm}$-Tris/ $\mathrm{HCl}, \mathrm{pH} 7.5$, and $100 \mu \mathrm{l} \mathrm{0.1} \mathrm{mM-PADAC}$. To initiate the reaction, $50 \mu$ l enzyme source, diluted with $10 \mathrm{~mm}$-potassium phosphate, $1 \mathrm{mg} \mathrm{BSA} \mathrm{ml}^{-1} \mathrm{pH} 7.5$, was added. The decrease in the $A_{570}$ was recorded over a 2 to 3 min period. The $\beta$-lactamase activities were routinely determined with PADAC as the substrate using the molar absorption coefficient of $52700 \mathrm{M}^{-1} \mathrm{~cm}^{-1}$. Activities with other $\beta$ lactam substrates also were determined spectrophotometrically at the wavelengths reported by Hirai et al. (1980), using the methods of Waley (1974) and Samuni (1975) for penicillins and of O'Callaghan et al. (1968) and Ross \& O'Callaghan (1975) for cephalosporins. One unit of $\beta$-lactamase is the amount that hydrolyses $1 \mu \mathrm{mol}$ of substrate min $^{-1}$.

The activities of glucose-6-phosphate dehydrogenase (DeMoss, 1955), alkaline phosphatase (von Tigerstrom, 1984) and ribonuclease (von Tigerstrom, 1980) were assayed by the published procedures.

Purification of $\beta$-lactamase. L. enzymogenes was grown in $1 \%(w / v)$ yeast extract, $100 \mu \mathrm{g}$ ampicillin $\mathrm{ml}^{-1}$ as indicated above. The cells from $355 \mathrm{ml}$ culture were obtained by centrifugation at $22^{\circ} \mathrm{C}$ for $15 \mathrm{~min}$ and the cell pellets were rinsed with $71 \mathrm{ml}$ of $10 \mathrm{mM}-\mathrm{Tris} / \mathrm{HCl}, 50 \mathrm{mM}-\mathrm{NaCl}$, $1.5 \mathrm{mM}-\mathrm{MgCl}_{2}, \mathrm{pH} 7.5$, and centrifuged for $5 \mathrm{~min}$ at $22^{\circ} \mathrm{C}$. The following steps were carried out at between 0 and $4{ }^{\circ} \mathrm{C}$ and centrifugations were at $15300 \mathrm{~g}$, except where indicated otherwise.

(a) Preparation of shock fluid. The cells were resuspended in $71 \mathrm{ml}$ $10 \mathrm{mM}$-Tris/ $\mathrm{HCl}, 200 \mathrm{mM}-\mathrm{MgCl}_{2}, \mathrm{pH} 8.4$, and mixed gently at $37^{\circ} \mathrm{C}$ for $15 \mathrm{~min}$. They were then centrifuged at $22^{\circ} \mathrm{C}$ for $5 \mathrm{~min}$, resuspended in $5 \mathrm{ml} 10 \mathrm{mM}-\mathrm{Tris} / \mathrm{HCl}, 200 \mathrm{mM}-\mathrm{MgCl}_{2}, \mathrm{pH} 8.4$, and quickly added to $350 \mathrm{ml} 10 \mathrm{mM}$-Tris, $2 \mathrm{~mm}$-EDTA, $1 \mathrm{~mm}$-dithiothreitol, pH 11.0, kept at $0{ }^{\circ} \mathrm{C}$. The suspension was mixed gently for $20 \mathrm{~min}$ to release the periplasmic components. The shocked cells were sedimented by centrifugation at 0 to $4{ }^{\circ} \mathrm{C}$ for $15 \mathrm{~min}$. The supernatant was retained and the $\mathrm{pH}$ was adjusted to $\mathrm{pH} 7.5$ with $1 \mathrm{M}-\mathrm{HCl}$ to yield $355 \mathrm{ml}$ of shock fluid. For some experiments the shocking procedure was done using $10 \mathrm{~mm}$-Tris/HCl, pH 8.4 as the shocking buffer.

(b) Concentration with CM-Sephadex. CM-Sephadex $(0.7 \mathrm{~g})$ was added to $353 \mathrm{ml}$ shock fluid. The suspension was stirred for $30 \mathrm{~min}$ and filtered using a $2.5 \mathrm{~cm}$ diameter column. The packed CM-Sephadex was then eluted with $50 \mathrm{ml} 10 \mathrm{~mm}$-Tris/HCl, $2 \mathrm{~mm}$-EDTA, $1 \mathrm{mM}$ dithiothreitol, $\mathrm{pH} 7.5$, and then with the same buffer at $\mathrm{pH} 11.0$. Fractions of $5.9 \mathrm{ml}$ were collected and fractions 39 to $42(23.5 \mathrm{ml})$, containing $78 \%$ of the $\beta$-lactamase activity applied to the column, were pooled for further purification. The $\mathrm{pH}$ of the pooled fractions was adjusted from 9.8 to 7.5 before dialysis against $10 \mathrm{mM}$-potassium phosphate, pH 7.5.

(c) CM52-cellulose chromatography. The dialysed preparation from step (b) was applied to a $2.5 \mathrm{~cm}$ diameter $\times 11 \mathrm{~cm}$ column of CM52cellulose equilibrated with $10 \mathrm{mM}$-potassium phosphate, pH 7.5 (starting buffer). It was then eluted with $50 \mathrm{ml}$ starting buffer followed by a linear gradient formed from $150 \mathrm{ml}$ starting buffer and $150 \mathrm{ml} 10 \mathrm{mM}$ potassium phosphate, $0.4 \mathrm{M}-\mathrm{KCl}, \mathrm{pH} 7.5$. The $\beta$-lactamase was eluted at approximately $0.13 \mathrm{M}-\mathrm{KCl}$ and fractions 32 to $34(15.5 \mathrm{ml})$ were pooled. They contained $59 \%$ of the activity applied to the CM52 column.

(d) Gel filtration. Purified preparation $(5 \mathrm{ml})$ from step (c) was applied to a $2.5 \mathrm{~cm}$ diameter $\times 42.5 \mathrm{~cm}$ column of Sephadex G-75 superfine equilibrated with $10 \mathrm{~mm}$-potassium phosphate, $0 \cdot 1 \mathrm{M}-\mathrm{KCl}$, $\mathrm{pH} 7.4$, and eluted with the same buffer, collecting $2.13 \mathrm{ml}$ fractions. The $\beta$-lactamase was eluted after $125.7 \mathrm{ml}$. About $50 \%$ of the $\beta$ lactamase activity applied to the column was recovered and there was no increase in specific activity.

PAGE molecular mass determination and estimation of isoelectric point. SDS-PAGE was carried out according to the method of Maizel (1971) as described previously (von Tigerstrom \& Stelmaschuk, 1985). Phosphorylase $b(97 \mathrm{kDa})$, BSA $(67 \mathrm{kDa})$, ovalbumin $(45 \mathrm{kDa})$, chymotrypsinogen $A(25 \mathrm{kDa})$ and cytochrome $c(12.5 \mathrm{kDa})$ were used as molecular mass markers.

Electrophoresis of the native $\beta$-lactamase was carried out in $7 \%(w / v)$ polyacrylamide gel as described by Maizel (1971) for basic proteins, except that sodium thioglycollate $(0.1 \mathrm{mM})$ was added to the electrophoresis buffer. After electrophoresis, the gel was covered for $3 \mathrm{~min}$ with $0.2 \mathrm{M}$-Tris/HCl, pH 7.5, and then for about $15 \mathrm{~min}$ with $60 \mu \mathrm{g}$ PADAC $\mathrm{ml}^{-1}$. Excess PADAC was then removed and the gel was photographed before staining the gel for protein by the method of Fairbanks et al. (1971). A duplicate gel was stained for protein only.

The molecular mass of the native $\beta$-lactamase was estimated by gel filtration using a $2.5 \mathrm{~cm}$ diameter $\times 42.5 \mathrm{~cm}$ column of Sephadex G-75 superfine. Blue dextran, Escherichia coli $\mathrm{C}_{4} \mathrm{~F}_{1}$ alkaline phosphatase $(84 \mathrm{kDa})$, ovalbumin $(45 \mathrm{kDa})$, secreted $L$. enzymogenes phosphatase $(25 \mathrm{kDa})$ (von Tigerstrom, 1984) and cytochrome $c(12.5 \mathrm{kDa})$ were used as the standards. The column was eluted with $10 \mathrm{mM}$-potassium phosphate, $0.1 \mathrm{M}-\mathrm{KCl}, 0.1 \mathrm{~mm}$-sodium thioglycollate, $\mathrm{pH} 7 \cdot 5$. Fractions of $2.3 \mathrm{ml}$ were collected. The $K_{\mathrm{av}}$, as defined by the supplier of Sephadex, was determined for each standard protein and used to determined graphically for each protein.

To estimate the isoelectric point of the $\beta$-lactamase, the elution of the enzyme from $\mathrm{CM}$-Sephadex by increasing the $\mathrm{pH}$ while maintaining a constant, low ionic strength (conductivity of $8 \mathrm{mS}$ ) was compared to the elution of pancreatic ribonuclease and cytochrome $c$. CM-Sephadex $(0.1 \mathrm{~g})$ was added to $50 \mathrm{ml}$ of $10 \mathrm{mM}-\mathrm{KCl}, 5 \mathrm{~mm}-\mathrm{Tris} / \mathrm{HCl}, 10 \mathrm{~mm}$ glycine, $\mathrm{pH} 7 \cdot 5$, containing $2 \cdot 1$ units $\beta$-lactamase, $2 \mathrm{mg}$ cytochrome $c$ and $0.5 \mathrm{mg}$ ribonuclease. The suspension was stirred for $30 \mathrm{~min}$ at $0{ }^{\circ} \mathrm{C}$ and poured into a $1.2 \mathrm{~cm}$ diameter column to obtain $5 \mathrm{ml}$ of packed CM-Sephadex below $6 \mathrm{ml}$ buffer (as a mixing chamber). The column was eluted with $16 \mathrm{ml}$ of $10 \mathrm{mM}-\mathrm{KCl}, 5 \mathrm{mM}$-Tris/ $\mathrm{HCl}, 10 \mathrm{~mm}$-glycine, pH 7.5, and then with $5 \mathrm{~mm}$-Tris, $10 \mathrm{mM}$-glycine adjusted to pH $10 \cdot 8$ with $\mathrm{KOH}$, and $1.35 \mathrm{ml}$ fractions were collected. The $\beta$-lactamase and ribonuclease activities and cytochrome $c$ concentrations were determined in each fraction and plotted against the $\mathrm{pH}$. The $\mathrm{pH}$ value corresponding to the midpoint of the increasing slope of the peak was determined graphically for each protein.

Inhibition of $\beta$-lactamase. The enzyme $\left(0.015\right.$ units $\left.\mathrm{ml}^{-1}\right)$ was incu-

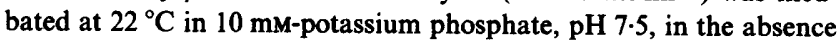
and in the presence of BSA $\left(1 \mathrm{mg} \mathrm{ml}^{-1}\right)$, with different concentrations of $p \mathrm{CMBS}$ and $p \mathrm{CMB}$ ranging from 0 to $100 \mu \mathrm{M}$. Clavulanic acid, in the presence of BSA, was used from 0 to $33 \mu \mathrm{M}$. The $\beta$-lactamase activities remaining after $10 \mathrm{~min}$ were determined and the results were used to estimate the inhibitor concentrations that would cause $50 \%$ inhibition of the enzyme.

Amino acid sequence. $\beta$-Lactamase was prepared as outlined above. After purification step $(b)$ the preparation was dialysed against $10 \mathrm{mM}$ - 
Tris/ $\mathrm{HCl}, \mathrm{pH} 8.0$, and freeze-dried. The Sequencing Laboratory of the Department of Biochemistry and Microbiology at the University of Victoria, Victoria, British Columbia, Canada, performed the SDSPAGE, blotting of the $28 \mathrm{kDa}$ protein band and the N-terminal sequence analysis.

Analytical procedures. Protein determinations were carried out by the Lowry method or, where suitable, by the direct spectrophotometric method (Warburg \& Christian, 1941). Cytochrome $c$ was determined by measuring $A_{530}$.

\section{Results and Discussion}

\section{Production of $\beta$-lactamase}

Preliminary results indicated that $L$. enzymogenes produced only a small amount of $\beta$-lactamase when grown in $1 \%$ yeast extract medium and that the enzyme was inducible. The rate of production of the $\beta$-lactamase was greatest during active growth of the organism in medium containing 100 to $200 \mu \mathrm{g}$ of inducer (ampicillin) (ml culture $)^{-1}$. No significant induction was observed during the stationary growth phase and little $\beta$-lactamase was produced if the medium containing the inducer was inoculated with a small inoculum (to give an $\mathrm{OD}_{600}$ of 0.05 ) and then allowed to grow for $22 \mathrm{~h}$ to the stationary phase. This was observed with both ampicillin and oxacillin and was probably due to the inducer being inactivated during the early period of growth. For these

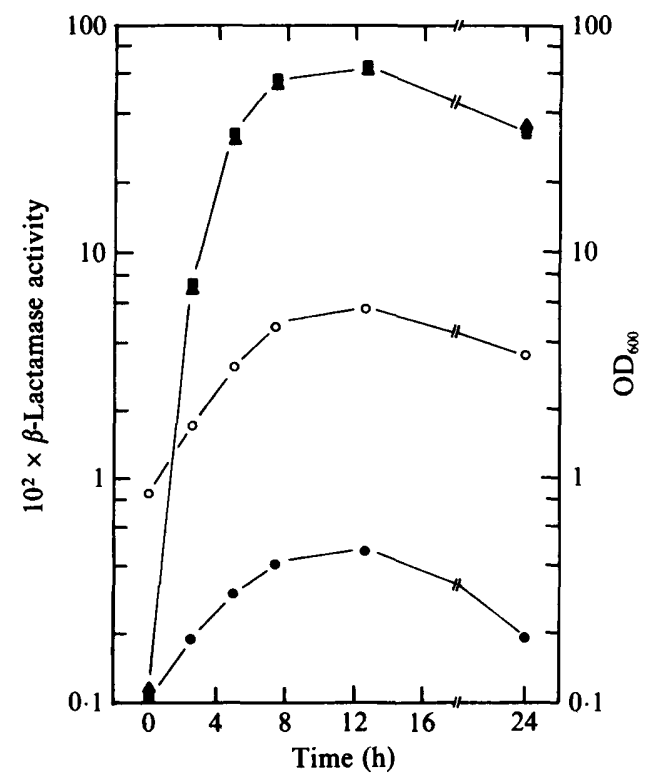

Fig. 1. Growth of $L$. enzymogenes and production of $\beta$-lactamase in the presence and absence of ampicillin. The organism was grown as described in Methods. The $O D_{600}$ of the cultures $(O)$ and the $\beta$ lactamase activities in cell-free extracts of cultures grown with $0 \mu \mathrm{g}$ (O), $100 \mu \mathrm{g}(\mathbb{C})$ and $200 \mu \mathrm{g}(\mathrm{N})$ ampicillin $\mathrm{ml}^{-1}$ were determined.
Table 1. Induction of $\beta$-lactamase with different $\beta$-lactam antibiotics

L. enzymogenes was grown with $100 \mu \mathrm{g} \mathrm{ml}^{-1}$ of the inducers as described in Methods. The $\beta$-lactamase activities were determined in cell-free extracts prepared from samples taken at the times indicated. PADAC was used as the substrate.

\begin{tabular}{|c|c|c|}
\hline \multirow[b]{2}{*}{ Inducer } & \multicolumn{2}{|c|}{$\begin{array}{l}10^{2} \times \beta \text {-Lactamase activity } \\
\quad \text { (units per } \mathrm{OD}_{600} \text { unit) }\end{array}$} \\
\hline & $5 \mathrm{~h}$ & $7.5 \mathrm{~h}$ \\
\hline None & 0.097 & 0.085 \\
\hline Ampicillin & $8 \cdot 7$ & $9 \cdot 1$ \\
\hline Oxacillin & $5 \cdot 3$ & $7 \cdot 0$ \\
\hline Methicillin & $4 \cdot 4$ & 6.8 \\
\hline Penicillin G & $6 \cdot 6$ & $7 \cdot 4$ \\
\hline Nafcillin & $7 \cdot 6$ & $12 \cdot 8$ \\
\hline Cephaloridine & $7 \cdot 3$ & 6.6 \\
\hline Cephalothin & 6.9 & $6 \cdot 2$ \\
\hline
\end{tabular}

reasons and because the enzyme could best be obtained by osmotic shocking of cells that were actively growing, the organism was grown routinely for 5 to $7 \mathrm{~h}$ (approximately 2 to 3 generations) with $100 \mu \mathrm{g}$ ampicillin $\mathrm{ml}^{-1}$ using a large inoculum. Fig. 1 shows the growth of $L$. enzymogenes and the production of $\beta$-lactamase with different inducer concentrations. The rate of growth was not affected by ampicillin, even at $300 \mu \mathrm{g} \mathrm{m}^{-1}$ (not shown). The highest yield of $\beta$-lactamase per unit of cell mass was usually obtained after 5 to $7 \mathrm{~h}$ and the enzyme activity was more than 100 -fold higher in induced cells than in uninduced cells. Nearly identical amounts of $\beta$ lactamase activity were obtained with ampicillin concentrations of $100 \mu \mathrm{g} \mathrm{ml}^{-1}$ and $200 \mu \mathrm{g} \mathrm{ml}^{-1}$. Using lower concentrations of ampicillin we found that $50 \%$ of maximal induction was obtained with $35 \mu \mathrm{g}$ ampicillin $\mathrm{ml}^{-1}$.

Although ampicillin was used routinely as the inducer, other $\beta$-lactam antibiotics also induced the Lysobacter $\beta$ lactamase (Table 1). The growth of $L$. enzymogenes was not inhibited by these antibiotics and most were less effective as inducers of $\beta$-lactamase than ampicillin. An exception was nafcillin, which produced the highest $\beta$ lactamase activity at $7.5 \mathrm{~h}$.

In a separate experiment, the induction of $\beta$-lactamase by ampicillin, which is hydrolysed rapidly, at 2 to $160 \mu \mathrm{g} \mathrm{ml}^{-1}$ was compared to the induction achieved by oxacillin, which is hydrolysed very slowly by the $\beta$ lactamase. Interestingly, the levels of $\beta$-lactamase produced at different concentrations of the two inducers were nearly identical. Therefore, the nature of the mechanism of induction and of the actual inducing molecule are not clear.

The addition of tryptophan, glycine, haemin or thiamin to growing cultures of $L$. enzymogenes had no 
Table 2. Purification of $\beta$-lactamase

The purification was very reproducible. Similar results were obtained twice at this scale and several times with smaller cultures.

\begin{tabular}{|c|c|c|c|c|c|}
\hline \multirow[b]{2}{*}{ Step } & \multirow[b]{2}{*}{ Fraction } & \multirow[b]{2}{*}{$\begin{array}{l}\text { Volume } \\
\text { (ml) }\end{array}$} & \multirow[b]{2}{*}{$\begin{array}{l}\text { Protein } \\
\text { (mg) }\end{array}$} & \multicolumn{2}{|c|}{$\beta$-Lactamase activity } \\
\hline & & & & (units) & $\begin{array}{c}\text { [units } \\
(\mathrm{mg} \text { protein })^{-1} \text { ] }\end{array}$ \\
\hline & Cell extract & 355 & 309 & 103 & 0.33 \\
\hline (a) & Shock fluid & 355 & 100 & 84 & 0.84 \\
\hline (b) & CM-Sephadex & $23 \cdot 5$ & $6 \cdot 4$ & 65 & 10 \\
\hline (c) & CM52 & $15 \cdot 5$ & $1 \cdot 0$ & 38 & 38 \\
\hline
\end{tabular}

effect on the growth of the organism or the $\beta$-lactamase activities. Thus, non-specific induction as seen with Aerobacter cloacae (Sanders, 1987) did not occur.

\section{Purification and stability}

The $\beta$-lactamase was purified 115 -fold with a $37 \%$ yield by using three simple steps. The purity of the final preparation was estimated from the results of SDSPAGE to be $80 \%$ to $90 \%$. A typical purification is summarized in Table 2.

In addition to full induction of the enzyme, an effective shocking procedure was important for a successful purification. During early experiments, a comparison of the shocking procedures of Neu \& Heppel (1965) and of Cheng et al. (1970) was made. These procedures released $31 \%$ and $66 \%$, respectively, of the $\beta$ lactamase present in the cell-free extract. The $\mathrm{Mg}^{2+}$ shocking procedure (Cheng et al., 1970) was modified slightly so that the shock fluid was obtained in $10 \mathrm{mM}$ Tris/ $\mathrm{HCl}, \mathrm{pH} 8 \cdot 4$, at $0{ }^{\circ} \mathrm{C}$ without the $10 \mathrm{mM}-\mathrm{MgCl}_{2}$. Under these conditions we found that few, if any, cytoplasmic components and only $3 \%$ of the outermembrane components were released into the shock fluid. This was determined by assaying glucose-6phosphate dehydrogenase as the cytoplasmic marker enzyme and the membrane-bound alkaline phosphatase (von Tigerstrom \& Stelmaschuk, 1985) as the outermembrane marker enzyme. Therefore, it is clear that the inducible $\beta$-lactamase of $L$. enzymogenes is a periplasmic enzyme.

The shocking procedure for the large-scale purification was carried out at $\mathrm{pH} 11$, as described in Methods. This increased the yield of the $\beta$-lactamase from that found using $\mathrm{pH} 8.4$, to about $84 \%$ (large-scale purification) or nearly $100 \%$ (small-scale purification). However, the specific activity was not increased, indicating that the additional release of the enzyme was non-specific.

The enzyme activity was not affected by short exposure to $\mathrm{pH} 5.0$ or to high $\mathrm{pH}$ values such as those used during the shocking procedure and the elution from CM-Sephadex. A considerable loss of enzyme activity was, however, noticed during storage in $10 \mathrm{~mm}$-potassium phosphate, $\mathrm{pH} 7.5$. The addition of $1 \mathrm{mg}$ bovine serum albumin $\mathrm{ml}^{-1}$ or the use of siliconized glassware allowed storage for several days at $0^{\circ} \mathrm{C}$ or several weeks at $-22^{\circ} \mathrm{C}$ without loss of activity. The addition of $1 \mathrm{~mm}$ dithiothreitol also stabilized the enzyme at $0{ }^{\circ} \mathrm{C}$ but in its presence there was almost complete loss of enzyme activity upon freezing and thawing. Exposure of the $\beta$ lactamase to $0 \cdot 1 \%$ SDS at room temperature also resulted in complete inactivation.

\section{Molecular mass and isoelectric point}

Fig. 2 shows SDS-PAGE of shock fluids from cells grown with and without ampicillin and of the $\beta$-lactamase preparations after steps $(b)$ and $(c)$ of the purification. Activity staining was not possible due to the instability of the enzyme in the presence of SDS, but it seemed clear that the band positioned just above the chymotrypsinogen $\mathrm{A}(25 \mathrm{kDa})$ was the $\beta$-lactamase. A corresponding band was not detectable in preparations from uninduced cells. A molecular mass for $\beta$-lactamase of $28.2 \mathrm{kDa}$ was calculated from each of two gels obtained on different occasions.

Non-denaturing PAGE of native $\beta$-lactamase from concentrated shock fluid [step $(b)$ of the purification] was also done, and the gel was stained first for $\beta$-lactamase activity and then for protein. $\beta$-Lactamase activity was only seen at the position coinciding with the major protein band (not shown). These results support the conclusion reached from the SDS-PAGE that the major inducible protein is the $\beta$-lactamase of $L$. enzymogenes.

The native enzyme was eluted from the Sephadex G75 column with a $K_{\text {av }}$ of 0.37 . The $K_{\text {av }}$ values of the standard proteins were $0 \cdot 14$ (E. coli alkaline phosphatase), 0.28 (ovalbumin), 0.45 (L. enzymogenes phosphatase) and 0.57 (cytochrome c). From these data an apparent molecular mass of approximately $30 \mathrm{kDa}$ was estimated for the $\beta$-lactamase. A comparison of the molecular mass values from the SDS-PAGE and Sephadex G-75 chromatography indicated that the native enzyme is composed of one polypeptide chain.

During step $(b)$ of the purification the $\beta$-lactamase was eluted from CM-Sephadex at $\mathrm{pH} 9 \cdot 8$. This suggested that the enzyme has a high isoelectric point. Since isoelectric points of very basic proteins are difficult to determine in isoelectric focusing gels, we compared the elution of the $\beta$-lactamase from CM-Sephadex to that of two other basic proteins. The $\beta$-lactamase, pancreatic ribonuclease and cytochrome $c$ were eluted from a small column of CM-Sephadex using a $\mathrm{pH}$ gradient as described in Methods. Pancreatic ribonuclease, with an isoionic point 


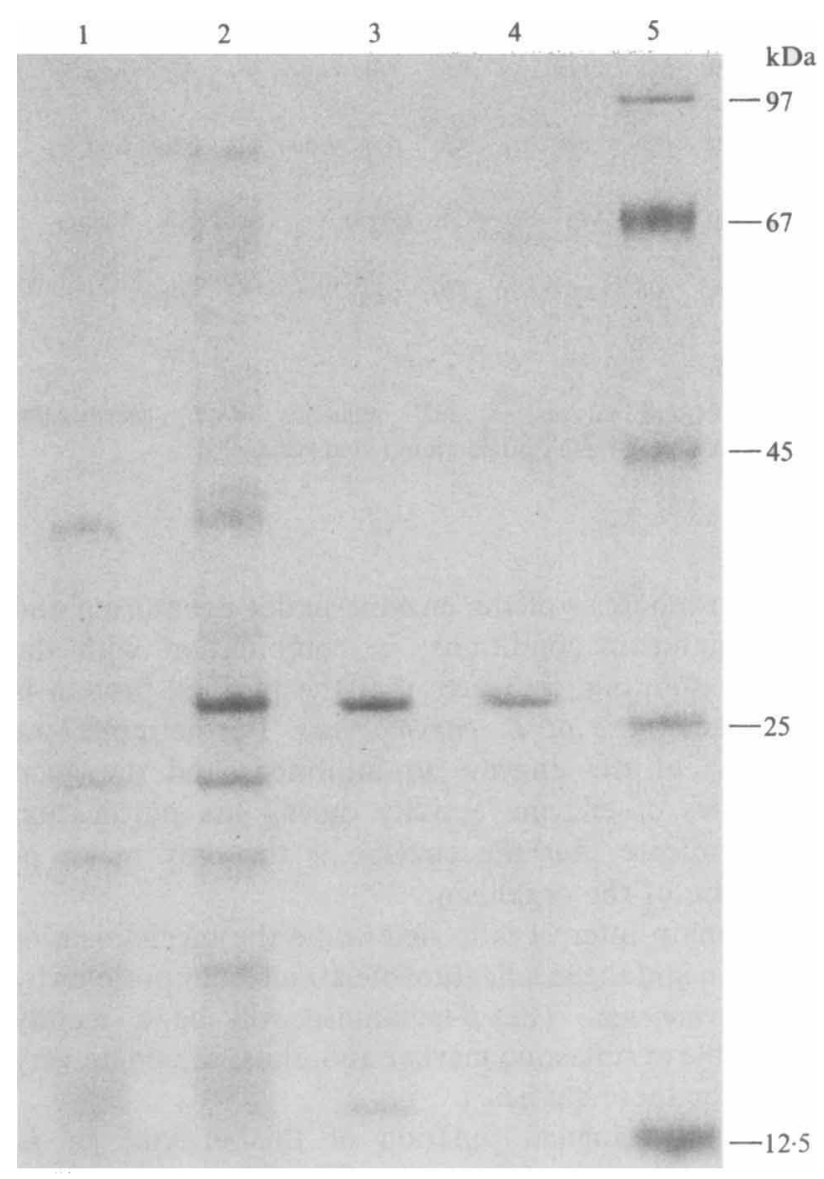

Fig. 2. SDS-PAGE of $L$. enzymogenes $\beta$-lactamase. The electrophoresis was carried out as described in Methods. The shock fluids were prepared in $10 \mathrm{~mm}$-Tris/ $\mathrm{HCl}, \mathrm{pH} 8.4$. They were concentrated 50 -fold by freeze-drying and samples were dialysed and prepared for SDSPAGE. The lanes contained: $1,15 \mu \mathrm{l}(\sim 60 \mu \mathrm{g}$ protein) shock fluid from cells grown without ampicillin; $2,15 \mu \mathrm{l}(\sim 90 \mu \mathrm{g}$ protein) shock fluid from cells grown with ampicillin; $3,10 \mu l(\sim 3 \mu \mathrm{g}$ protein) after purification step $(b) ; 4,20 \mu \mathrm{l}(\sim 1 \cdot 3 \mu \mathrm{g}$ protein) after purification step (c); and 5, 20 $\mu \mathrm{l}$ standard protein mixture (phosphorylase $b$, BSA, ovalbumin, chymotrypsinogen A, cytochrome $c$ ).

of 9.6 and an isoelectric point of 9.45 (Richards \& Wyckoff, 1971), was eluted at pH 9.40. The $\beta$-lactamase was eluted together with cytochrome $c$ at $\mathrm{pH} 9.60$. Mammalian cytochrome $c$ has an isoionic point and isoelectric point of 10.04 and this value is unaffected by the presence of various positive ions according to Barlow \& Margoliash (1966). However, an isoelectric point of 9.6 is reported by Bio-Rad (1988). In the absence of any ionic effect, a basic protein should be eluted from a cation exchanger at its isoelectric $\mathrm{pH}$ and if the ionic strength of the solution is increased it should be eluted slightly below the isoelectric $\mathrm{pH}$. Since the proteins in this study were eluted at low ionic strength with the hydroxyl and glycine ions as the only major negative ions, we estimate that the isoelectric point of the $\beta$-lactamase is similar to that of cytochrome $c$, i.e. approximately $\mathbf{9 . 6}$ or higher.

\section{Inhibitors of $\beta$-lactamase}

EDTA at concentrations of up to $5 \mathrm{~mm}$ had no inhibitory effect on the $\beta$-lactamase activities in cell-free extracts and in shock fluids of the induced cells or, as expected, in more highly purified enzyme preparations. This indicated that the organism does not also produce a $\beta$ lactamase which is dependent on metal ions for activity and is in agreement with the PAGE results, which indicated that the organism produces only one major $\beta$ lactamase. The concentrations of the other inhibitors tested were chosen to give between $0 \%$ and greater than $90 \%$ inhibition under the conditions described in Methods. The inhibitor concentrations causing approximately $50 \%$ inhibition were determined to be $25 \mu \mathrm{M}$ for $p \mathrm{CMBS}$ and $35 \mu \mathrm{M}$ for $p \mathrm{CMB}$ in the presence of BSA and $0.08 \mu \mathrm{M}$ for $p \mathrm{CMBS}$ and $0.04 \mu \mathrm{M}$ for $p \mathrm{CMB}$ in the absence of BSA. Clavulanic acid at $0.28 \mu \mathrm{M}$ inhibited the $\beta$-lactamase by $50 \%$. The sensitivity to $p C M B S$ and $p C M B$ indicates that the enzyme requires thiol groups for activity, and this is in agreement with the stabilizing effect of dithiothreitol.

\section{Substrate specificity of $\beta$-lactamase}

The activities of the $\beta$-lactamase with nine different substrates and the $K_{\mathrm{m}}$ values for the substrates that were readily hydrolysed were determined in order to further characterize the enzyme (Table 3 ). The $K_{\mathrm{m}}$ values and maximum velocity $(V)$ values were obtained from $1 / v$ versus $1 /[\mathrm{S}]$ plots using seven different concentrations for each substrate, except where indicated otherwise in Table 3.

The enzyme was relatively non-specific, degrading both penicillins and cephalosporins, but it was considerably more active with ampicillin and penicillin $G$ than with cephaloridine and cephalothin. Oxacillin and cloxacillin were hydrolysed very slowly, if at all. Although the induction pattern of $\beta$-lactamases in different organisms is complex (Sanders, 1987), it is interesting to note that oxacillin was a poor substrate but a relatively good inducer of the $L$. enzymogenes enzyme.

Both cefotaxime and PADAC were hydrolysed slowly. However, because of the high molar absorption coeffcient of PADAC, its use as the substrate for the routine assay nevertheless resulted in a very sensitive assay method.

According to this substrate profile, the L.enzymogenes $\beta$-lactamase could belong to either the group $2 \mathrm{~b}$, group 
Table 3. Rates of hydrolysis by shock fluid-derived $\beta$ lactamase and $K_{m}$ values for some $\beta$-lactam substrates

\begin{tabular}{lccr}
\hline & \multicolumn{2}{c}{$V$} & \\
\cline { 2 - 3 } Substrate & $\left(\right.$ units ml $\left.{ }^{-1}\right)$ & $(\%)^{*}$ & $\begin{array}{r}K_{\mathrm{m}} \\
(\mu \mathrm{M})\end{array}$ \\
\hline Penicillin G & 5.3 & 100 & 116 \\
Ampicillin & 10.9 & 206 & 438 \\
Carbenicillin & 2.0 & 37 & 141 \\
Oxacillin & $<0.06 \dagger$ & $<1$ & ND \\
Cloxacillin & $<0.06 \dagger$ & 1 & ND \\
Cephaloridine & 0.87 & 16 & 91 \\
Cephalothin & 1.88 & 35 & 57 \\
Cefotaxime & $0.41 \dagger$ & 8 & ND \\
PADAC & 0.12 & 2 & ND \\
\hline \hline
\end{tabular}

ND, Not determined.

* The activity obtained with penicillin $G$ was assigned a value of $100 \%$.

$\dagger$ The activities were obtained with 120 mM-oxacillin or cloxacillin and 100 mM-cefotaxime. Therefore, they may not represent maximum velocities.

$2 b^{\prime}$ or, possibly, group $2 c$ of $\beta$-lactamases (Bush, $1989 a, b)$.

\section{$N$-terminal amino acid sequence}

The $\beta$-lactamase of $L$. enzymogenes was induced and purified for amino acid sequencing as described in Methods. As shown in Fig. 3, a complete sequence was obtained up to amino acid 20 and a partial sequence for amino acids 21 to 41 . Although the sequence contains many amino acids with degenerate codons, the results have been used to construct an oligonucleotide probe which is being used to characterize the gene for the $\beta$ lactamase.

\section{Concluding remarks}

The results of our experiments show that the $\beta$-lactamase of $L$. enzymogenes is an inducible, periplasmic enzyme of about $28 \mathrm{kDa}$ which has a very high isoelectric point. It is relatively non-specific with respect to the substrate it hydrolyses and is strongly inhibited by $p C M B S, p C M B$ and clavulanic acid but not by EDTA. According to these properties the enzyme is similar to the group $2 b \beta$ lactamase produced by Pseudomonas cepacia (Hirai et al., 1980; Bush, 1989b). Furthermore, preliminary data suggest that the enzyme seems to be coded for by a chromosomal gene. We were unable to isolate $\beta$ lactamase-negative strains after growth with $50 \mu \mathrm{g}$ and $100 \mu \mathrm{g}$ ethidium bromide $\mathrm{ml}^{-1}$ or after extended cultivation at the organism's maximum growth temperature $\left(36^{\circ} \mathrm{C}\right)$ (results not shown).

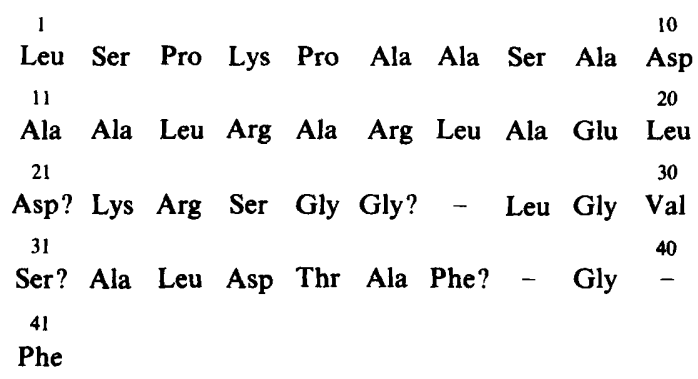

Fig. 3. N-terminal amino acid sequence of $L$. enzymogenes $\beta$-lactamase. -, Undetermined amino acid residue.

Electrophoresis of the enzyme under denaturing and non-denaturing conditions, in combination with the activity staining, indicates that the purified protein is the $\beta$-lactamase of $L$. enzymogenes. Furthermore, the response of the enzyme to inhibitors and the good recoveries of enzyme activity during the purification steps indicate that the enzyme is the only major $\beta$ lactamase of the organism.

Our main interest is to determine the mechanism of secretion and the localization of extracellular proteins by $L$. enzymogenes. The $\beta$-lactamase will be a readily detectable periplasmic marker and, thus, should be very useful for these studies.

The physiological function of this enzyme in $L$. enzymogenes is also of interest. The $\beta$-lactamases have been reviewed by Richmond \& Sykes (1973) and more recently by Sanders (1987) and Bush $(1989 a, b, c)$. The interst in these enzymes stems mainly from their possible role in the resistance of pathogenic bacteria to $\beta$-lactam antibiotics. However, non-pathogenic organisms also produce these enzymes and $L$. enzymogenes seems to be a typical example of such a Gram-negative bacterium. The function of $\beta$-lactamases in these organisms was discussed by Richmond \& Sykes (1973) but they did not arrive at a definite conclusion and it is not clear why $L$. enzymogenes and other non-pathogenic bacteria produce this enzyme. It may be a protective mechanism for some other organisms, but $L$. enzymogenes seems to have a natural resistance to $\beta$-lactam antibiotics without the $\beta$ lactamase. The rate of growth of $L$. enzymogenes was not affected by $300 \mu \mathrm{g}$ ampicillin $\mathrm{ml}^{-1}$ or $100 \mu \mathrm{g} \mathrm{ml}^{-1}$ of the other $\beta$-lactam antibiotics listed in Table 1 . This lack of inhibition was particularly surprising in the case of antibiotics like oxacillin which were not degraded by the enzyme. Impermeability of the outer membrane does not seem to be a factor in the resistance since the antibiotics function as inducers. Perhaps the target structure for the antibiotic is insensitive. Furthermore, it is unlikely that L. enzymogenes encounters high enough inducer concentrations in its natural habitat to significantly increase the 
$\beta$-lactamase levels. It also is unlikely that the enzyme has a nutritional function as do many of the other hydrolases that this organism produces since synthesis of the $\beta$ lactamase does not seem to be affected by catabolite repression. Thus, the metabolic function of the $\beta$ lactamase in $L$. enzymogenes is as yet unknown and the induction of the enzyme is a poorly understood and, perhaps, fortuitous event.

This work was supported by the Natural Sciences and Engineering Research Council of Canada.

\section{References}

BARLOW, G. H. \& MARGOLIASH, E. (1966). Electrophoretic behavior of mammalian-type cytochrome c. Journal of Biological Chemistry 241, 1473-1477.

Bio-RAD (1988). Chromatography, Electrophoresis, Immunochemistry, Molecular Biology, HPLC, Liquid handling (Catalogue N), p. 102.

Bush, K. (1989a), Characterization of $\beta$-lactamases. Antimicrobial Agents and Chemotherapy 33, 259-263.

BusH, K. (1989b). Classification of $\beta$-lactamases: groups 1, 2a, $2 \mathrm{~b}$, and $2 b^{\prime}$. Antimicrobial Agents and Chemotherapy 33, 264-270.

Bush, K. (1989c). Classification of $\beta$-lactamases: groups $2 c, 2 d, 2 e, 3$, and 4. Antimicrobial Agents and Chemotherapy 33, 271-276.

Cheng, K.-J., Ingram, J. M. \& Costerton, J. W. (1970). Release of alkaline phosphatase from cells of Pseudomonas aeruginosa by manipulation of cation concentration and of $\mathrm{pH}$. Journal of Bacteriology 104, 748-753.

ChRISTENSEN, P. \& COOK, F. D. (1978). Lysobacter, a new genus of nonfruiting gliding bacteria with a high base ratio. International Journal of Systematic Bacteriology 28, 367-393.

DEMOss, R. D. (1955). Glucose-6-phosphate and 6-phosphogluconic dehydrogenase from Leuconostoc mesenteroides. Methods in Enzymo$\operatorname{logy} 1,328-334$.

Fairbanks, G., Steck, T. L. \& Wallach, D. F. H. (1971). Electrophoretic analysis of major polypeptides of the human erythrocytic membrane. Biochemistry 10, 2606-2616.

HedGes, A. \& Wolfe, R. S. (1974). Extracellular enzyme from Myxobacter AL-1 that exhibits both $\beta$-1,4-glucanase and chitosanase activities. Journal of Bacteriology 120, 844-853.

Hirai, K., Iyobe, S., Inoue, M. \& Mitsuhashi, S. (1980). Purification and properties of a new $\beta$-lactamase from Pseudomonas cepacia. Antimicrobial Agents and Chemotherapy 17, 355-358.

JACKSON, R. L. \& MATSUEDA, G. R. (1970). Myxobacter AL-1 protease. Methods in Enzymology 19, 591-599.

MaIzel, J. V., JR (1971). Polyacrylamide gel electrophoresis of viral proteins. Methods in Virology 5, 179-246.

NeU, H. L. \& HePPEL, L. A. (1965). The release of enzymes from Escherichia coli by osmotic shock and during formation of spheroplasts. Journal of Biological Chemistry 246, 3685-3692.
O'Callaghan, C. H., Muggleton, P. W. \& Ross, G. W. (1968). Effects of $\beta$-lactamase from Gram-negative organisms on cephalosporins and penicillins. In Antimicrobial Agents and Chemotherapy, pp. 57-63. Washington, DC: American Society for Microbiology.

REICHENBACH, H. \& DWorkin, M. (1981). The order Cytophagales (with addenda on the genera Herpetosiphon, Saprospira, and Flexithrix). In The Prokaryotes, pp. 356-379. Edited by M.P. Starr, H. Stolp, H. G. Truper, A. Balows \& H. G. Schlegel. New York: Springer-Verlag.

RICHARDS, F. M. \& WYCKOFF, H. W. (1971). Bovine pancreatic ribonuclease. In The Enzymes vol. IV, pp. 647-806. Edited by P. Boyer. New York: Academic Press.

Richimond, M. H. \& SyKES, E. B. (1973). The $\beta$-lactamases of Gramnegative bacteria and their possible physiological role. Advances in Microbial Physiology 9, 31-88.

ROSENBERG, E. \& Varon, M. (1984). Antibiotics and lytic enzymes. In Myxobacteria, Development and Cell Interactions, pp. 109-125. Edited by E. Rosenberg. New York: Springer-Verlag.

Ross, G. W. \& O'Callaghan, C. H. (1975). $\beta$-Lactamase assays. Methods in Enzymology 43, 69-85.

SAMUNI, A. (1975). A direct spectrophotometric assay and determination of Michaelis constants for the $\beta$-lactamase reaction. Analytical Biochemistry 63, 17-26.

SANDERS, C. C. (1987). Chromosomal cephalosporinases responsible for multiple resistance to newer $\beta$-lactam antibiotics. Annual Review of Microbiology 41, 573-593.

voN TigersTrom, R. G. (1980). Extracellular nucleases of Lysobacter enzymogenes: production of the enzymes and purification and characterization of an endonuclease. Canadian Journal of Microbiology 26, 1029-1037.

VON TIGERSTROM, R. G. (1981). Extracellular nucleases of Lysobacter enzymogenes: purification and characterization of a ribonuclease. Canadian Journal of Microbiology 27, 1080-1086.

von TIgerstrom, R. G. (1984). Production of two phosphatases by Lysobacter enzymogenes and purification and characterization of the extracellular enzyme. Applied and Environmental Microbiology 47, 693-698.

voN TIGERSTROM, R. G. \& STELmasChUK, S. (1985). Localization of the cell-associated phosphatase in Lysobacter enzymogenes. Journal of General Microbiology 131, 1611-1618.

von Tigerstrom, R. G. \& StelmaschuK, S. (1986). Purification and characterization of the outer membrane associated alkaline phosphatase of Lysobacter enzymogenes. Journal of General Microbiology 132, 1379-1387.

von Tigerstrom, R. G. \& Stelmaschuk, S. (1987). Purification and partial characterization of an amylase from Lysobacter brunescens. Journal of General Microbiology 133, 3437-3443.

von Tigerstrom, R. G. \& StelmaschuK, S. (1989). Localization and characterization of lipolytic enzymes produced by Lysobacter enzymogenes. Journal of General Microbiology 135, 1027-1035.

WALEY, S. G. (1974). A spectrophotometric assay of $\beta$-lactamase action on penicillins. Biochemical Journal 139, 789-790.

WarbURG, O. \& Christian, W. (1941). Isolierung and Kristallisation des Garungsferments Enolase. Biochemische Zeitschrift 310, 384-421.

WHITAKER, D. R. (1970). The $\alpha$-lytic protease of a myxobacterium. Methods in Enzymology 19, 599-613. 